\title{
VAN DIE NYL TOT STELLENBOSCH: ANTIEKE EGIPTIESE VOORWERPE OP STELLENBOSCH
}

\author{
I Cornelius (Universiteit van Stellenbosch)
}

\section{Inleiding}

Egipte is soos Suid-Afrika deel van die kontinent van Afrika en daar is voorbeelde van hoe antieke Egiptiese motiewe in die Suid-Afrikaanse boukuns voortleef (Cornelius 2001). Afgesien van argitektoniese voorbeelde is daar ook oorspronklike antieke Egiptiese artefakte in SuidAfrikaanse versamelings en 'n aantal hiervan vorm tans deel van die uitstalling "Lewende Antieke" van die Dept. Antieke Studie in die SASOL-Kunsmuseum van die Universiteit van Stellenbosch. Die uitstalling bestaan uit meer as 200 voorwerpe uit die antieke wêreld en is 'n seleksie van die Antieke versameling van Iziko Museums van Kaapstad wat kragtens in leenooreenkoms tussen die Universiteit van Stellenbosch en Iziko Museums vir twee jaar op bruikleen is. ${ }^{1}$

Die doel van die artikel is om hierdie antieke Egiptiese voorwerpe aan 'n breër publiek bekend te stel, asook om die voorwerpe self behoorlik te beskryf en met ander voorwerpe in Egiptiese versamelings en die breër internasionale Egiptologie en vakliteratuur in verband te bring. ${ }^{2}$ Die amptelike rekords en dokumentasie van Iziko Museums is of onvolledig, of foutief, of in sommige gevalle bestaan dit glad nie. 'n Deeglike katalogisering en beskrywing is 'n desideratum. ${ }^{3}$

Iziko Museums van Kaapstad besit 'n klein maar nogtans interessante versameling Egiptiese voorwerpe (Boshoff \& Cornelius 2002). Die meeste hiervan kom uit die opgrawings van Flinders Petrie by Kafr Tarkhan en Amarna. Daar is ook voorwerpe uit die predinastieke (voor 3000 v.C.) tyd, ${ }^{4}$ waarskynlik uit Naqada en enkele voorwerpe van opgrawings van Guy Brunton, die Britse argeoloog wat saam met sy eggenote die kunstenares Winifred (neé Newberry) in SA geleef en begrawe is (Boshoff \& Cornelius 2002:134). Die ander voorwerpe is op die oorsese oudhedemark gekoop, of is skenkings.

1 Sien http://academic.sun.ac.za/as/news.htm vir foto's van die uitstalling en voorwerpe. Die museum is in Ryneveldstraat 52 (in die ou Bloemhofskool langs Wilgenhof) en openingstye is: Dins.- Vr.: 09:00 - 16:30; Sa: 09:00 - 16:00.

$2 \quad$ Hierdie artikel doen verslag oor ' $\mathrm{n}$ navorsingsprojek (US-Subkomitee A: 2005). 'n Aantal voorwerpe is elders gepubliseer (Boshoff 1995/1996 en Boshoff \& Cornelius 2002) - hierdie artikel sal daarop uitbrei beide wat die voorwerpe en beskrywing/analise/literatuur betref. Voorwerpe word volgens die bestaande Iziko-nommers (vetgedruk) aangedui. Die foto's word hier gepubliseer met die toestemming van Iziko Museums van Kaapstad (met besonderse dank aan Anlen Boshoff en Ester Esmyol). Die voorwerpe is ook reeds in drie lesings aan 'n breër publiek in 2005 bekendgestel (byeenkoms van die Wes-Kaapse tak van die KVSA, The Egyptian Society of SA, en kongres van die SA-Vereniging vir Nabye Oosterse Studie).

3 Dieselfde is waar van alle antieke versamelings in die land. Daar is die bydraes in Scholia en Akroterion (sien bv. Ryan 2004) wat die Klassieke betref, maar sover dit die Ou Nabye Ooste aangaan bestaan dit nie (sien egter Rademeyer 1988 en Ryan 2004).

4 Die kronologie van Shaw 2004:183-184 word gevolg.

Akroterion 50 (2005) 125-136 
Die voorwerpe word in verskillende kategorieë voorgestel, maar met inagneming van die feit dat so ' $\mathrm{n}$ indeling nie in die antieke wêreld bestaan het nie. ${ }^{5}$ So byvoorbeeld word die palette (2.3) as alledaagse voorwerpe beskryf, alhoewel dit in graftes gevind is. Die uitstalling self is in groepe ingedeel: skrif, godsdiens, versiering, oorlog, alledaagse voorwerpe, en daar is ook ' $n$ aangepaste weergawe van 'n vroeë Egiptiese graf.

\section{Alledaagse Voorwerpe en Gebruiksartikels}

\section{$2.1 \quad$ Keramiek}

Die grootste gedeelte van die versameling bestaan uit ongeglasuurde keramiek (pottebakkersware) wat o.a. deur die destydse kurator van die Antieke versameling in Iziko Museums, Anlen Boshoff, in haar Stellenbosse M.A. bestudeer is (1995/1996). ${ }^{6}$ Hierdie artefakte is meesal uit die predinastieke- en vroegdinastieke (dinastie 1 en 2) tyd (3000-2686 v.C.) en kom uit Tarkhan en waarskynlik Naqada.

'n Interessante tipe is wat Petrie Palestynse ware (Boshoff 1995:75-76) genoem het omdat dit ook in Palestina voorkom en deur Egiptiese pottebakkers aangepas is. Dit dui op vroeë handelskontakte. Een voorbeeld is 2544 (= Fig. 1). ${ }^{7}$ 'n Tweede voorbeeld word beskryf as swartrantpotte ("black-topped ware") omdat dit aan die bokant die tipiese swart rant het (Boshoff 1995:73) (1958 = Fig. 2). 'n Derde voorbeeld (1840) is interessant - 'n langerige Tarkhanvaas van 32,8 cm. met'n pottebakkersmerk (Fig. 3 = Boshoff 1995:128-129).

\subsection{Faïence ${ }^{8}$}

Faïence is in Egipte van kwarts gemaak, waarskynlik om duur turkoois of lasuursteen na te maak, maar dit is ook as 'n magiese materiaal gesien vanweë sy kleur wat'n manifestasie van lig is (Friedman 1998:8-10). Die godin van geboorte, Hathor, is "dame van faïence" genoem. Twee voorwerpe verdien aandag. Die eerste is 'n besonderse mooi drinkbeker ("chalice") in die vorm van die Egiptiese blou lotusblom (nymphaea caerulea) $(\mathbf{1 7 2 2}=$ Fig. $\mathbf{4}=$ Boshoff \& Cornelius 2002:138, Pl. I:D). Die herkoms is onbekend, maar die stuk dateer moontlik uit die 21-22ste dinastie (1069-715 v.C.). Die blom en blare is in reliëf en die beker staan op 'n groot uiteenlopende voetstuk. 'n Amper identiese stuk is in die versameling van die Bibel+Orient

5 Sien bv. die indeling van die Petrie Museum (http://www.petrie.ucl.ac.uk/search/object_drill/index.php): "clothing and personal effects, art, writing and sealing, religious and funerary equipment, tools and weapons, transport and animal equipment, containers and related objects, buildings and furniture, animal, vegetable and mineral remains."

$6 \quad$ Sien ook Boshoff \& Cornelius 2002:137 en Pl. I:A, C = 1936 (silindriese pot met versiering) en 2520 (ronde pot met illustrasie van 'n boot).

7 Die vuurhoutjieboksie op die foto is daar om 'n idee van die relatiewe grootte van die voorwerpe te gee.

8 Vir die belangrikste materiaal wat in Egipte gebruik is, sien nou Nicholson 2000, vir faïence spesifiek Friedman 1998; Nicholson 1993 en "Faience" in OEAE 1:491-496. 
Museum in Fribourg (Switserland). ${ }^{9}$ Uit die graf van Tutankhamen kom 'n pragtige albasterlamp en "wensbeker" in lotusvorm (Edwards 1976:86, 88). Die lotus (Egipties sesjen M9 ${ }^{10}$ ) is eerder ' $\mathrm{n}$ waterlelie. Dit was in Egipte die simbool van Bo-Egipte (suide) en die god Nefertem (Leitz 2002:IV:221c), van die skepping, nuwe lewe en liefde, maar het ook farmakologies-medisinale funksies gehad. ${ }^{11}$

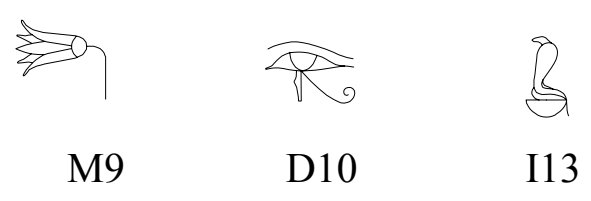

'n Langwerpige fles (2587 = Fig. 5) is versier met twee udjat-oë en 'n Egiptiese kobra (uraeus). Beide die udjat en uraeus is bekende Egiptiese simbole. Die udjat (D10) as die "geneesde oog van Horus" was 'n simbool van beskerming par excellence. ${ }^{12}$ Die uraeus (I13) of Egiptiese kobra (Naja haje) is die heraldiese simbool van Onder-Egipte (noorde), die godin Wadjet in die Deltastad Buto en kom voor in die Nebti-naam van die farao, maar is ook met die god Ra verbind..$^{13}$ Die uraeus was deel van die koninklike hooftooisel en die farao dra dikwels 'n uraeus op sy voorkop soos op die goue dodemasker van Tutankhamen (Edwards 1976:134).

\subsection{Ander voorwerpe}

Antieke Egiptiese vroue is (danksy Kleopatra VII) beroemd vir die versorging van hulle liggame. Of Kleo wel in melk gebad het, weet ons nie, maar wat ons wel weet is dat Egiptenare ooggrimering gebruik het. Die doel was ook nie net kosmeties nie, maar om gesondheidsredes as ontsmettingsmiddel en weens die skerp son. ${ }^{14}$

Grimering is op palette aangemaak wat veral in die vroeë periodes voorkom. ${ }^{15}$ Die beroemde vroeë palette van farao's soos Narmer $(63 \mathrm{~cm}$. hoog!) uit c. 3000 v.C. is meer seremonieel van aard (Shaw 2004:Fig. 1a-b). Op uitstalling is vier voorbeelde (1878, 1917, 1893, 2552). Een

9 http://www.bible-orient-museum.ch/shop/postkarten/_seiten/2002/2002_5.php (ÄFig 2002.4) = Bickel 2004:122-123, Abb. 39a (\#39) met literatuur. Sulke vase word soms aan die gode gewy (Bickel 2004:Abb. 39b). Sien ook die voorbeeld in die Petrie Museum (UC 15891 = MacDonald 2005:61 en http://www.petrie.ucl.ac.uk/detail/details/index_no_login.php?objectid=UC15891\&accesscheck $=\% 2$ Fdetail\%2 Fdetails\%2Findex.php).

$10 \quad$ Klassifikasie volgens Gardiner 1988, sien Wilkinson 1992.

11 Vgl. Cornelius 2004:80 met verwysings; sien ook Wilkinson 1992:120-121 en nou Meader \& Demeter 2004. Die geliefde in die Bybelse boek Hooglied (2:1) is soos 'n "lotus" (OAV/NAV "lelie," in Hebreeus susjan - 'n Egiptiese leenwoord en waar die naam Susan(na) vandaan kom) - vgl. Keel 1994:77-81. Volgens Herodotus (II:92) het die Egiptenare die lotus geeët.

12 Vgl. Wilkinson 1992:42-43.

13 Vgl. Johnson 1990; Leitz 2002:II:269-277; Wilkinson 1992:108-109.

14 Sien "Toiletries and cosmetics" in OEAE 3:412-417. Die hiëroglief D7 wys 'n oog met 'n geverfde onderlid en die woord "skoonheid" word met dié teken as determinatief geskryf.

15 Sien Cialowicz 1999 en "Palettes" in OEAE 3:17-20. 
hiervan is van leiklip en in die vorm van 'n vis (2552 = Fig. 6), uit Mostagedda (Brunton 1937:70, 154, P1. xliii, 9), ${ }^{16}$ c. $3150-3050$ v.C. ${ }^{17}$ In die middel van die Ou Ryk is kohl (swart galena) as grimering gebruik en in 'n klein potjie met water gemeng. Die albaster-grimeerpotjie is in Rigga gevind en dateer uit die 12de dinastie (1985-1795 v.C.) $(\mathbf{1 8 0 2}=$ Fig. 7).

Benewens voorwerpe van klei en faïence is daar ook 'n bak en stamper van argoniet $(\mathbf{1 6 1 5}=$ Fig. 8 en 1756 = Fig. 9). Laasgenoemde kom uit Middel-Egipte (van Brunton) uit die 19de dinastie (1295-1186 v.C.).

\section{Godsdienstige- en Grafvoorwerpe}

Aangesien die Isis terra-cotta $(\mathbf{7 1 / 1 4 1}=$ Fig. 10a $)$ en Bes-vaas $(1942=$ Fig. $10 b)$ reeds elders in groter detail behandel is (Boshoff \& Cornelius 2002:135-137, 138 met Pl. I:A en II:B), sal dit net kortliks vermeld word. Die terra-cotta beeld die beroemde en welbekende godin in haar latere Grieks-Romeinse vorm (Selena-Luna) uit. ${ }^{18}$ 'n Klein flessie met oë, neus/mond en ore toon die huisgodjie Bes wat vroue en kinders beskerm het. ${ }^{19}$ Hierdie flessie is waarskynlik as 'n houer vir melk vir babas gebruik en die figuur van Bes het beskerming gebied.

Daar is miniatuurbeeldjies en amulette van bekende Egiptiese gode: bronsfigure van Osiris en Horus (1617 en 1659) en 'n faïence valkie met 'n kroon (2582) (Fig. 11a-c). ${ }^{20}$ Sulke amulette is as gelukbringers en veral vir beskerming gedra. ${ }^{21}$

Vir die antieke Egiptenaar was 'n qerset nefret = "goeie begrafnis" van uiterste belang. ${ }^{22}$ Die dooie se liggaam is gemummifiseer (om dit behoue te laat bly) en in 'n kis en in 'n graf met al die nodige grafgoedere geplaas. ${ }^{23}$ Hieronder tel die grafmodelle, kanopusflesse en usjabtis.

Op uitstalling is ook 'n Ptolomese gemummifiseerde voël (1718 = Fig. 12), na alle waarskynlikheid ' $\mathrm{n}$ valkie wat met die god Horus verbind is. ${ }^{24}$ Diere is gemummifiseer - as troeteldiere, en as dode-offers, maar veral omdat sekere diere as heilig beskou is en met spesifieke gode en godinne verbind is - bv. die ibis van Thot.

16 Verwysing met dank aan Lambert Vorster van Malmesbury.

17 Sien Cialowicz 1999:21-24 en by

http://www.petrie.ucl.ac.uk/detail/details/index_no_login.php?objectid=UC10734

\&accesscheck $=\% 2$ Fdetail\%2Fdetails\%2Findex.php.

18 Vgl. DNP 5:1125-1132 en NP 6:966-972.

19 Vgl. by http://www.digitalegypt.ucl.ac.uk/tarkhan/ucarchive/uc37334.jpg en

http://www.petrie.ucl.ac.uk/detail/details/index_no_login.php?objectid=UC37334\&accesscheck=\%2Fdetail\%2 Fdetails\%2Findex.php, maar eerder

http://www.petrie.ucl.ac.uk/detail/details/index_no_login.php?objectid $=$ UC30761\&accesscheck=\%2Fdetail $\% 2$ Fdetails\%2Findex.php. Sien vir albei nou die inskrywings met literatuur en verwysings na die ikonografie in Leitz 2002:I:61-79 (Bes) en III:834-835 (Isis) en "Bes" en "Isis" in OEAE 1:179-181 en 2:188-191.

20 Vgl. Leitz 2002:V:230-297 en II:528-569 en "Horus" en "Osiris" in OEAE 2:119-122 en 615-619.

21 Die Egiptiese terme is meket/nehet ("beskerm") en wedja ("wel-wees"). Sien vir amulette Andrews 1994 en in OEAE 1:81.

22 Sinuhe wil na sy land terugkeer sodat hy in sy geboorteland begrawe kan word (Lichtheim in Hallo 1997:80a).

23 Sien Taylor 2001 en nou Ikram 2003; Grajetzki 2004 en Retief \& Cillers 2004.

24 Dit is as dit nie 'n vervalsing (bestaande uit gras en stokkies) is soos baie ander voorbeelde nie. Net 'n behoorlike "CAT-scan" sal hieroor uitsluitsel kan gee. Vir dieremummies sien o.a. Taylor 2001:Chap. 8. 


\subsection{Kanopusfles}

'n Integrale deel van die repertorium van antieke Egiptiese begrafnisgoedere is die sogenaamde kanopusflesse ("canopic jars"). ${ }^{25}$ Die term is ongelukkig 'n vergissing aangesien dit verbind word met die menskoppige flesse wat deur die inwoners van die hawe Canopus aanbid is as verpersoonliking van Osiris. Canopus is vernoem na die Homeriese karakter wat die stuurman van Menelaus was. ${ }^{26}$ Flesse met mensvormige koppe word egter nog steeds so genoem. Die kanopusflesse kom voor in 'n groep van vier flesse wat gewoonlik gemaak is van albaster, klip, hout of keramiek en waarin die binnegoed van die dooie dan bewaar is. Die gebruik gaan terug na die moeder van Khufu (c. 2500 v.C.). Later (vanaf 2000 v.C.) het die flesse vier unieke deksels gekry, in die vorm van die vier sogenaamde "seuns van Horus" wat ook die vier kardinale kompaspunte beskerm het - die menskoppige Imseti vir die lewer is verbind met Isis en die suide, die bobbejaankop Hapi vir die longe met Neftis en die noorde, die jakkalskop Duamutef vir die maag is verbind met Neith en die ooste en die valkkop Qebehsenuef vir die binnegoed met Serket en die weste. ${ }^{27}$

Die voorbeeld op uitstalling is van albaster (1724 = Fig. 13) en het die kop van 'n valk (Qebehsenuef). 'n Tweede kanopusfles is in Kaapstad op uitstalling in die Iziko Slawelosie en het weer die kop van Imseti. Die voorwerpe dateer moontlik uit die 26ste Saïetiese dinastie (664-525 v.C.).

\subsection{Usjabti $^{28}$}

Die usjabti of sjabti/sjawabti is figure in die vorm van mummies en daar is magiese spreuke daarop. Die figure hou gereedskap vas en is "werkers van die dood" - hulle kon opgeroep word om werk namens die dooie te verrig, vandaar die moontlike betekenis van die Egiptiese "antwoorder." Honderde (soveel as 365, 700 in die graf van farao Seti I) is in graftes geplaas. Dit kom veral sedert die Middelryk (2000 v.C.) voor en is van klei, faïence of hout gemaak. Die meeste bevat spreuk ("hoofstuk") 6 van die Dodeboek waarin die usjabti opgeroep word om te werk (Faulkner 1985:36).

Vorms (L68/13 = Fig. 14) is vir die massaproduksie van usjabtis gebruik. Daar is verskeie usjabtis in die Iziko-versameling, sewe is op uitstalling in Stellenbosch (1619; L68/17 [= Fig. 15]; 86/343 a \& d; 1752; 1600; 1594).

\subsection{Grafmodelle}

Die Egiptenare het verskillende "modelle" in die graf geplaas as plaasvervanger vir die ware Jakob wat alledaagse aktiwiteite uitbeeld en wat deur magie "lewe" kon kry. ${ }^{29}$ 'n Goeie

25 Sien Dodson 1994; "Canopic jars and chests" en "Four sons of Horus" in OEAE 1:231-235 en 561-563; Taylor 2001:65-76.

26 DNP 6:247 en NP 2:1057-1058.

27 In die populêre film "The Mummy" (met Arnold Vosloo in die hoofrol) is daar ongelukkig foutiewelik vyfstuks.

28 Sien "Funerary figurines" in OEAE 1:567-570; Schneider 1977; Stewart 1995; Taylor 2001:Chap. 4. 
voorbeeld is die graf van Meket-Ra uit die Middelryk (c. 2000 v.C.) wat deur Winlock (1955) opgegrawe is. Sulke modelle is meesal van hout, maar kan ook van klei wees. Twee voorbeelde sal aandag geniet.

Vrouefiguurtjies $(\mathbf{8 6} / \mathbf{3 3 9} \& \mathbf{3 4 0}=$ Fig. 16) van hout met arms wat kan beweeg is nie speelgoedpoppe nie, maar een tipe van die modelfiguurtjies wat uit ander graftes bekend is. ${ }^{30}$ Waarskynlik kom hierdie figuurtjie uit die Middelryk.

Die boot speel in die Ou Egiptiese alledaagse lewe 'n belangrike rol, maar ook in die Egiptiese mitologie en geloof in die lewe na die dood. ${ }^{31}$ Soos Ra vaar die dooie met 'n boot deur die onderwêreld. ${ }^{32}$ Langs die "Groot Piramide" van Khufu (Cheops) is 'n volledige voorbeeld van werklike grootte gevind, ander voorbeelde kom uit Abydos. ${ }^{33}$ Modelbote is van hout, maar ook van klei. 'n Voorbeeld van klei op uitstalling kom uit Abusir el-Malaq (Delta) uit die 1ste-2de eeu n.C. $(\mathbf{7 5 / 1 6}=$ Fig. 17$){ }^{34}$

\section{$3.4 \quad$ Begrafniskegel}

Die voorwerp $(\mathbf{1 6 0 9}$ = Fig. 18) word in die Iziko-rekords as 'n kleistempel ("clay stamp") beskryf, maar is eerder 'n begrafniskegel ("funerary cone"). ${ }^{35}$ In die verlede is sulke koniese voorwerpe van gebakte klei op verskillende wyses benoem: van brode tot grensstene. Dit is egter voorwerpe (10-15 cm. lank) wat in mure van grafte met die skerper punt geplaas is om 'n fries te vorm. ${ }^{36}$ Aan die ander breër ent is 'n hiëroglief-inskripsie met die naam en titels van die grafeienaar aangebring. Sulke voorwerpe gaan terug na die 11 de dinastie (c. 2000 v.C.) alhoewel die meeste uit die 18de dinastie (1550-1300 v.C.) kom. 'n Voorbeeld hiervan is uit die 18de dinastie (1420 v.C.) graf van Sennefri en tans in die Britse Museum in Londen. ${ }^{37}$ Daar is ook heelwat vergelykingsmateriaal in die Petrie-versameling. ${ }^{38}$

29 "Models" in OEAE 2:424-428; Taylor 2001:99-105; Tooley 1995.

$30 \quad$ Vgl. bv. Taylor 2001:Fig. 61

31 Sien Taylor 2001:103-105.

32 Vgl. in hierdie verband die universele gedagte van die dooie wat per boot oor die rivier van die dood vaar: in Mesopotamië vervoer Ursjanabi vir Gilgamesj (X:iii-iv) oor die Khubur (Galter 1999) en in die Klassieke wêreld is dit Charon en die Styx (DNP 2:1107-1108 = NP 3:202-203 en DNP 11:1064). Bootmodelle van bitumen en silwer is in die graftes van Ur gevind (Galter 1999:431a en Pritchard 1969:Fig. 105).

33 O'Connor 1991 - vir bote in Egipte sien Vinson 1994.

34 Vgl. in die Petrie Museum by http://www.petrie.ucl.ac.uk/detail/details/index_no_login.php?objectid=UC16608\&accesscheck=\%2Fdetail\%2 Fdetails\%2Findex.php.

35 Vgl. "Funerary cones" in OEAE 1:565-567; Ryan 1986 en 2004-2005.

36 Sien die voorstellings by http://www.digitalegypt.ucl.ac.uk/thebes/tombs/conesinfo.html; Bickel 2004:Abb. 30c-d, Ryan 2004-2005 en Schulz \& Seidel 1998:250, Fig. 197.

$37 \mathrm{http} / / /$ www.thebritishmuseum.ac.uk/compass/ixbin/hixclient.exe?_IXDB_=compass\&_IXSR_=bk4\&_IXSS $=$ IXFPFX_\%3dgraphical $\% 252$ ffull $\% 252 \mathrm{f} \% 26$ _IXNOMATCHES_\%3dgraphical $\% 252 \mathrm{fno}$ matches $\% 252 \mathrm{eht}$ $\mathrm{ml} \% 26 \% 2524 \% 2 \mathrm{~b} \% 2528$ with\%2bv2_searchable_index $\% 2529 \% 2 \mathrm{bsort} \% 3 \mathrm{~d} \% 252 \mathrm{e} \% 26$ _IXDB_\%3dcompass $\% 26 \% 257 \mathrm{bUPPER} \% 257 \mathrm{~d} \% 253 \mathrm{av} 2$ free_text tindex $\% 3 \mathrm{dfunerary} \% 2 \mathrm{bcone} \% 26$ IXsearchterm $\% 3 \mathrm{dfunerary} \%$ 252520 cone\&_IXFIRST_$=1 \&$ IXMAXHITS $=1{ }_{-}=1$ _IXSPFX_egraphical $/$ full $/ \&_{-}{ }_{-}$IXsearchterm $=$funerary $\% 252$ 0cone\&submit-button= summary.

38 Sien Stewart 1986 en by http://www.petrie.ucl.ac.uk/detail/details/index_no_login.php?objectid=UC30174\& accesscheck $=\% 2 \mathrm{Fdetail} \% 2 \mathrm{Fdetails} \% 2 \mathrm{Findex}$.php en verder. 


\section{Slot}

Hierdie artikel wil 'n bydrae lewer tot die studie van Aegyptiaca in Suid-Afrika. Die versameling Egiptiese artefakte in Iziko Museums van Kaapstad bly uniek en dit is verblywend dat die nalatenskap van dié antieke beskawing aan die walle van die Nyl nou ook te sien is op die walle van die Eersterivier.

Wat nodig is, is dat die ander Egiptiese voorwerpe in Kaapstad ook deeglik bestudeer word. Om alle Aegyptiaca in ons land te versamel, deeglik te bestudeer en deel van 'n gesofistikeerde digitale visuele databasis te maak, bly 'n dringende desideratum.

\section{BIBLIOGRAFIE}

Andrews, C 1994. Amulets of ancient Egypt. London: British Museum Press.

Bickel, S 2004. In ägyptischer Gesellschaft. Fribourg: Academic Press.

Boshoff, A 1995. The Early Dynastic ceramics of Kafr-Tarkhan [c. 3000-2800 BC] with special reference to examples in the South African Cultural History Museum, Cape Town (Ongepubliseerde M.A. Universiteit van Stellenbosch).

Boshoff, A 1996. Egyptian ceramics from Kafr-Tarkhan [c. 3050-2686 BC] in the South African Cultural History Museum, Cape Town. Cape Town: SACHM.

Boshoff, A \& Cornelius, I 2002. The Egyptian collection in Iziko Museums of Cape Town, South Africa, in: Eldamaty, M \& Trad, M (eds.), Egyptian Museum. Collections around the world: studies for the Centennial of the Egyptian Museum. Cairo: Supreme Council of Antiquities, American University in Cairo Press, Vol. I, 133-142.

Brunton, G 1937. Mostagedda and the Tasian culture. London: Quatrich.

Cialowicz, K 1999. Les palettes Égyptiennes aux motifs zoomorphes et sans décoration. Kraków: Uniwersytet Jagiellonski.

Cornelius, I 2001. Van Karnak tot Kakamas: die naleef van ou Egipte in die Suid-Afrikaanse boukuns. Akroterion 46:75-91.

Cornelius, I 2004. The many faces of the goddess. The iconography of the Syro-Palestinian goddesses Anat, Asherah, Astarte and Qedeshet c. 1500-1000 BCE (Orbis Biblicus et Orientalis 204). Göttingen: Vandenhoeck \& Ruprecht \& Fribourg: University Press.

DNP = Cančik, H \& Schneider, H (Hrsg.) 1996-2003. Der Neue Pauly: Enzyklopädie der Antike. Stuttgart \& Weimar: Metzler.

Dodson, A 1994. The canopic equipment of the kings of Egypt. London: Kegan Paul.

Edwards, I E S 1976. Treasures of Tutankhamun: New York: The Metropolitan Museum of Art.

Faulkner, R O 1985. The Ancient Egyptian Book of the Dead. London: British Museum Press.

Friedman, F D 1998. Gifts of the Nile: ancient Egyptian faience. Minerva 9/3:8-17.

Galter, H 1999. Hubur, in: Van der Toorn, K, Becking, B \& Van der Horst, P W (eds.), Dictionary of deities and demons in the Bible. 2nd ed. Leiden: Brill; Grand Rapids: Eerdmans, 430-431.

Gardiner, A H 1988. Egyptian grammar: being an introduction to the study of hieroglyphs. Oxford: Griffith Institute.

Grajetzki, W 2004. Burial customs in ancient Egypt: life in death for rich and poor. London: Duckworth. Hallo, W W (ed.) 1997. Context of Scripture I. Leiden: Brill. 
Ikram, S 2003. Death and burial in ancient Egypt. Harlow: Longman.

Johnson, S B 1990. The cobra goddess of Ancient Egypt. London: Kegan Paul International.

Keel, O 1994. The Song of Songs: a continental commentary. Minneapolis: Fortress.

Leitz, C (Hrsg.) 2002. Lexikon der ägyptischen Götter und Götterbezeichnungen I-VII (OLA 110-117). Leuven: Peeters.

MacDonald, S 2005. The Petrie Museum. A world class collection at risk. KMT 16/3:59-66.

Meader, J \& Demeter, B 2004. The Egyptian blue water lily. KMT 15/2:57-63.

Nicholson, P T 1993. Egyptian faience and glass. Princes Risborough, Buckinghamshire.

Nicholson, P T \& Shaw, I (eds.) 2000. Ancient Egyptian materials and technology. Cambridge: University Press.

NP = Cančik, H \& Schneider, H (eds.) 2002-2005. Brill's New Pauly: Encyclopedia of the ancient world. Leiden: Brill.

O'Connor, D 1991. Boat graves and pyramid origins. Expedition 33/3:5-17.

OEAE = Redford, D B (ed.) 2001. The Oxford encyclopedia of Egypt. Oxford: Oxford University Press.

Pritchard, J B 1969. The Ancient Near East in pictures. Princeton: University Press.

Rademeyer, R 1988. Decoration on the Egyptian coffin and mummy in the Durban Natural History Museum. DE ARTE 37:61-71.

Retief, F P \& Cilliers, L 2004. Die dood en doodshantering in oud-Egipte, 3100-332 v.C. Akroterion 49:7-15.

Ryan, A J 2004. In the museum. Akroterion 49:119-124.

Ryan, D P 1986. The archaeological analysis of inscribed Egyptian funerary cones. (aanlyn: http://www.plu.edu/ ryandp/cones.html)

Ryan, D P 2004-2005. Cone conundrum. A brief look at an ancient Egyptian funerary phenomenon: the funerary cone. KMT 15/4:59-66.

Schneider, H D 1977. Shabtis. An introduction to the history of ancient Egyptian funerary statuettes with a catalogue of the collection of Shabtis in the National Museum of Antiquities at Leiden. Leiden: Rijksmuseum van Oudheden.

Shaw, I 2004. Ancient Egypt. A very short introduction. Oxford: University Press.

Schulz, R \& Seidl, M (eds.) 1998. Egypt: The world of the pharaohs. Cologne: Könemann.

Stewart, H M 1986. Mummy cases \& inscribed funerary cones in the Petrie Collection. Warminster.

Stewart, H M 1995. Egyptian shabtis. Princes Risborough, Buckinghamshire: Shire.

Taylor, J 2001. Death \& the afterlife in Ancient Egypt. London: The British Museum Press.

Tooley, A M J 1995. Egyptian models and scenes. Princes Risborough, Buckinghamshire: Shire.

Vinson, S 1994. Egyptian boats and ships. Princes Risborough, Buckinghamshire: Shire.

Wilkinson, R H 1992. Reading Egyptian art: a hieroglyphic guide to Ancient Egyptian painting and sculpture. London: Thames and Hudson.

Winlock, H E 1955. Models of daily life in Ancient Egypt from the tomb of Meket-Re' at Thebes. Cambridge, Massachusetts: Harvard University Press. 
Fig. 1

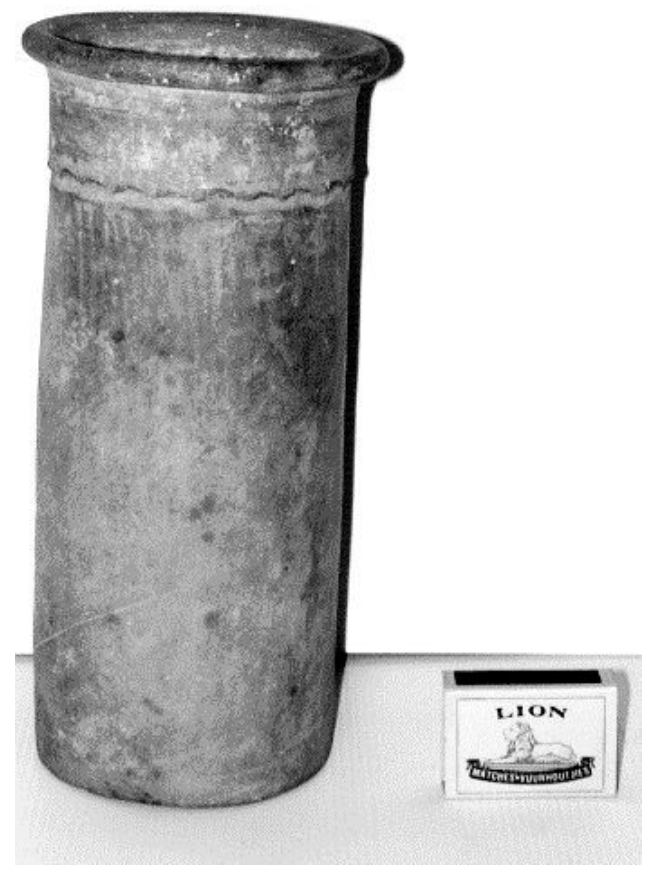

Fig. 2

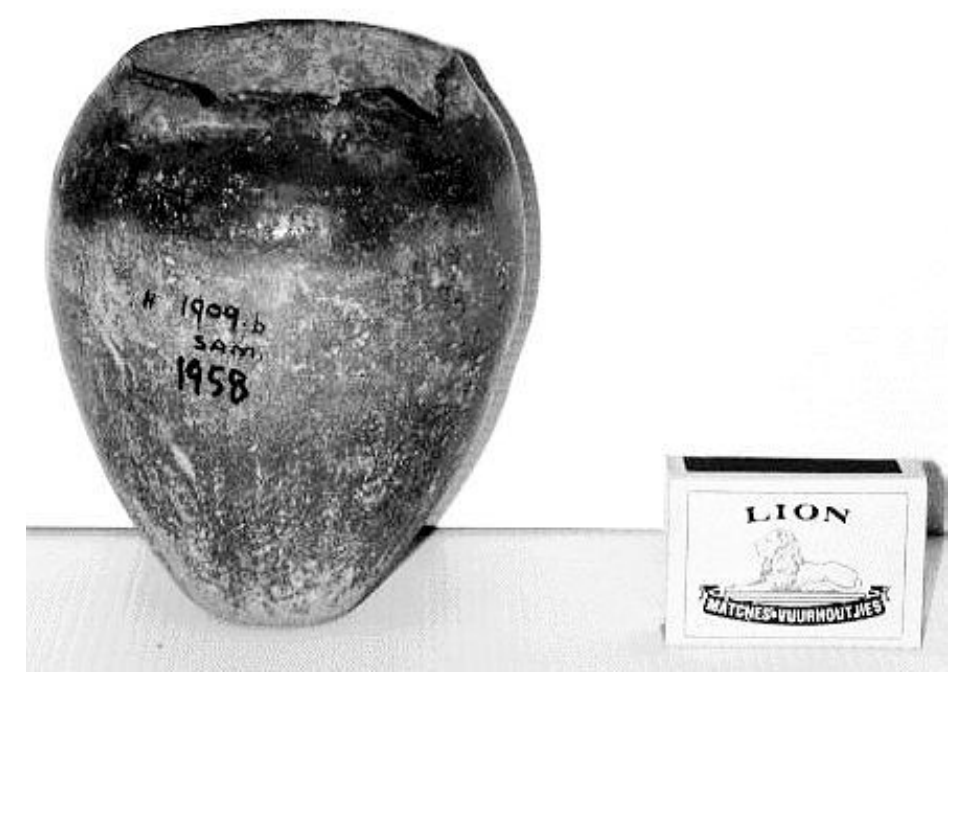

Fig. 3

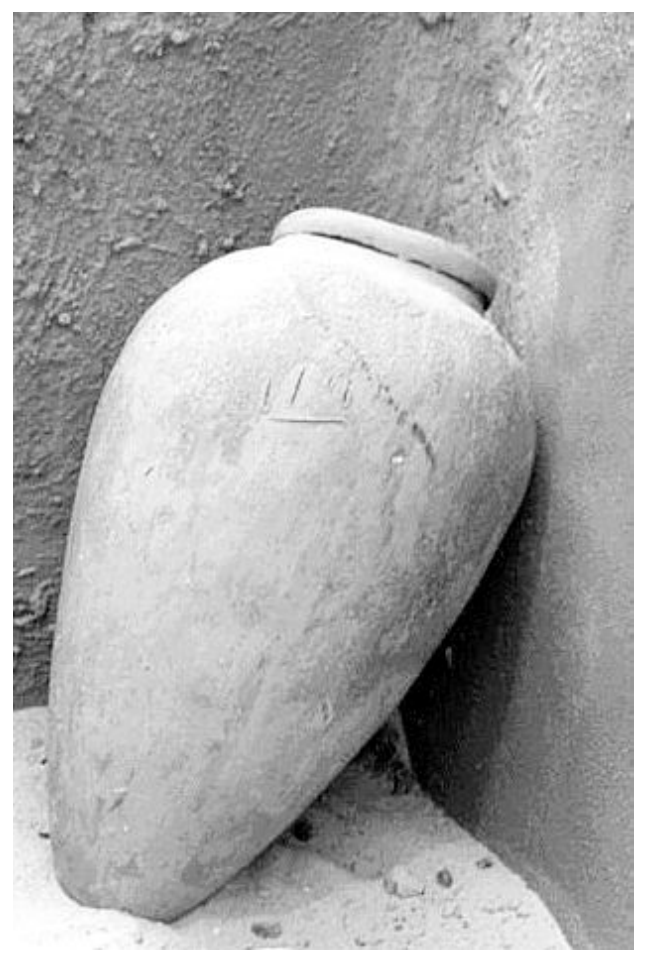

Fig. 4

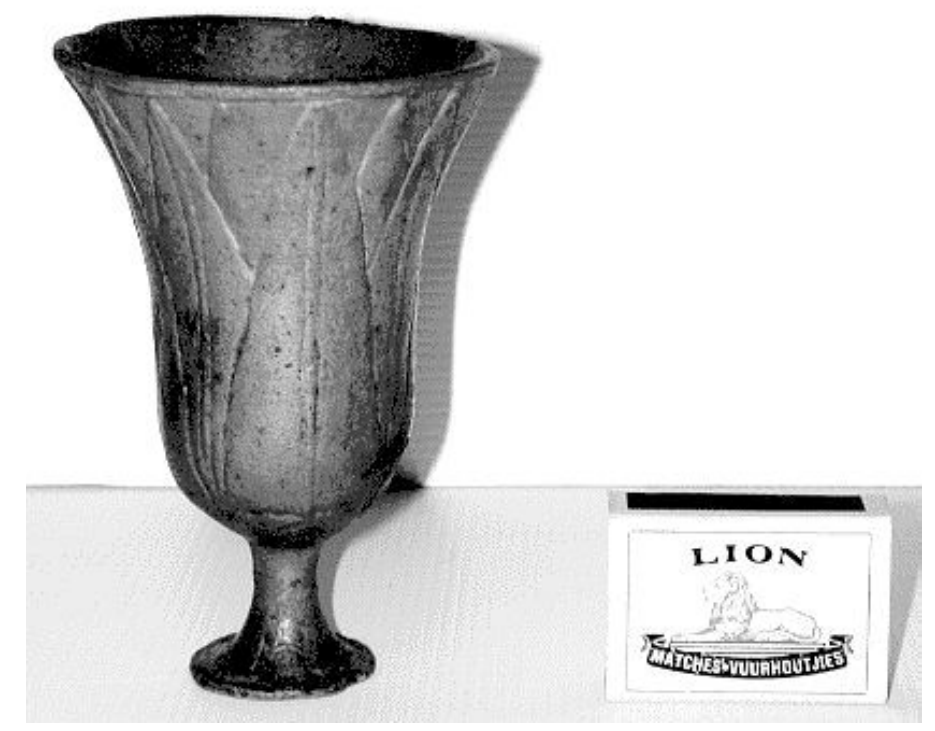


Fig. 5

Fig. 6

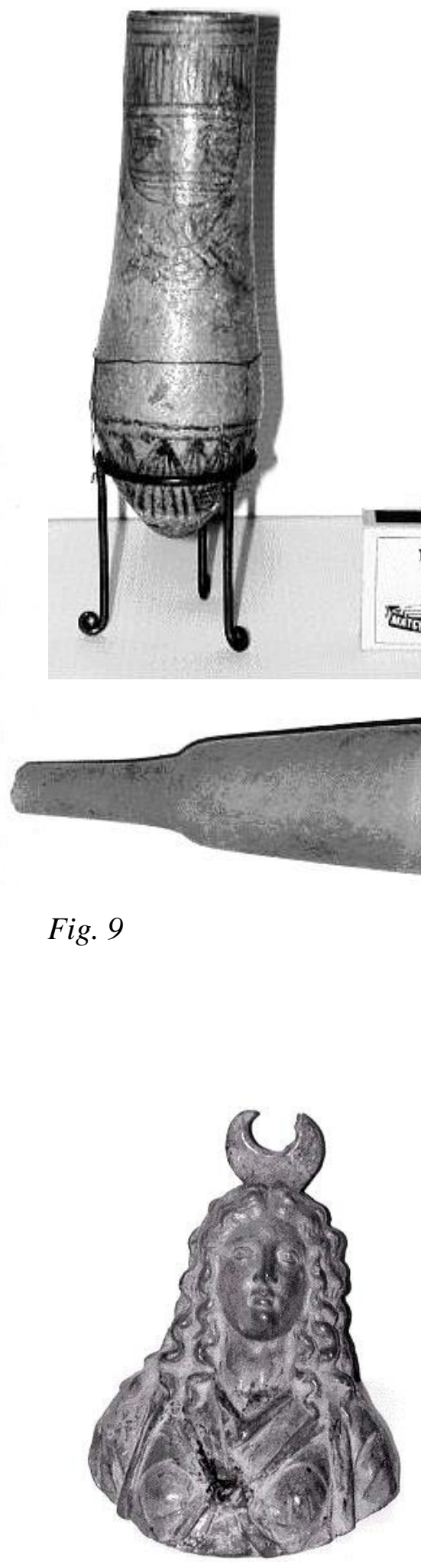

Fig. 10a

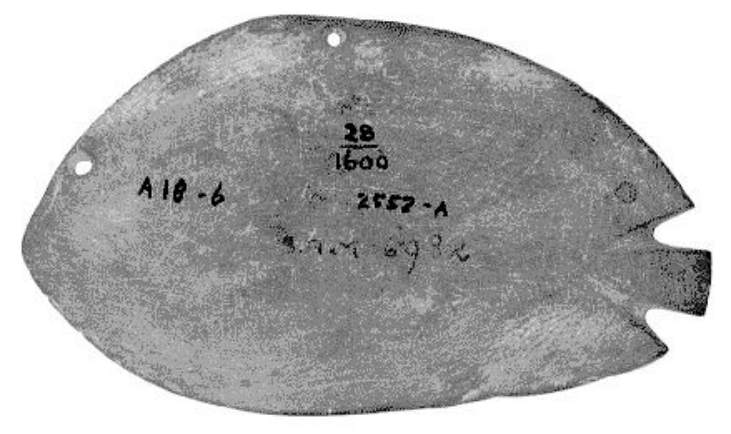

Fig. 7
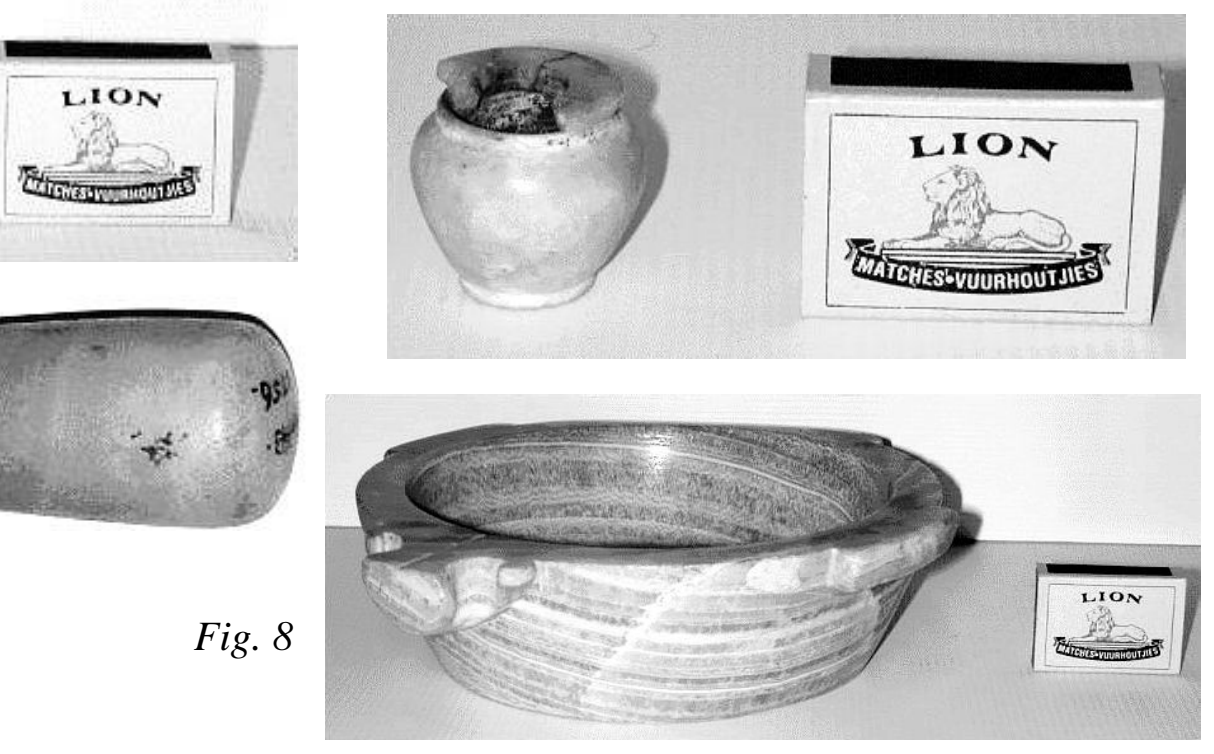

\section{Fig. 8}

Fig. $10 b$

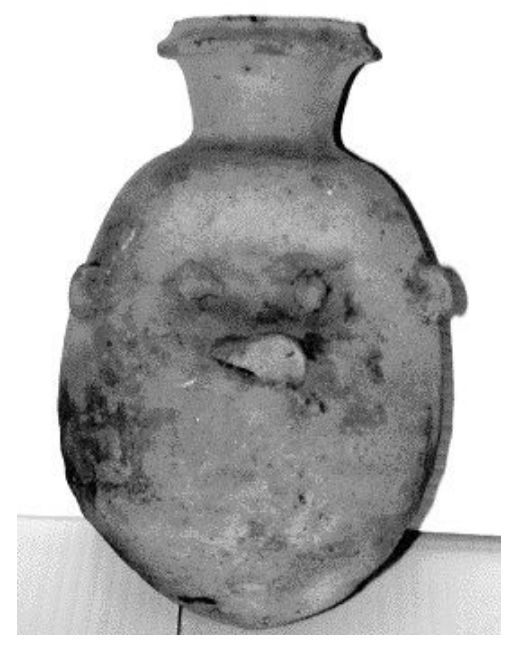


Fig. 11a

Fig. 11b

Fig. 11c
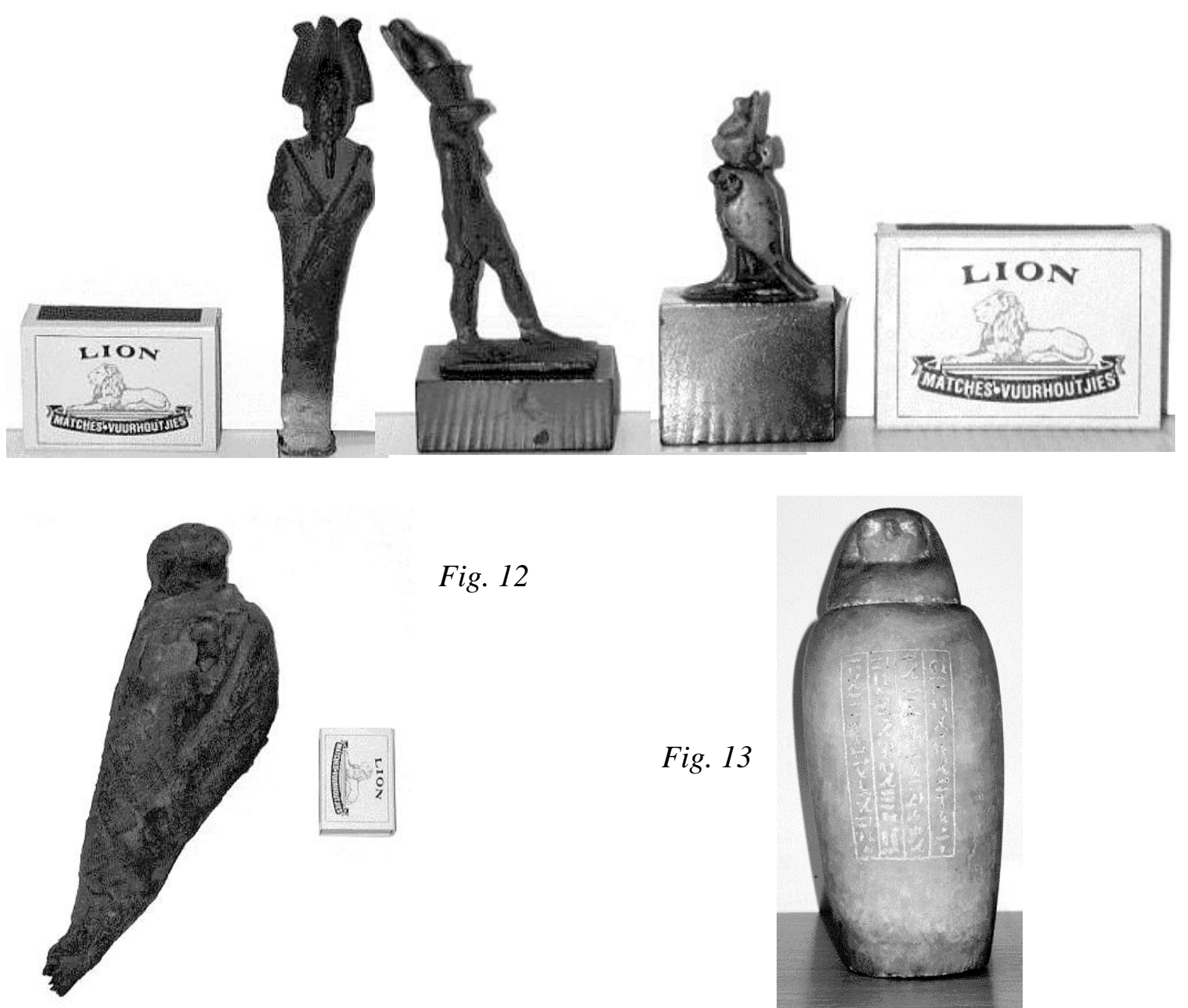

Fig. 12

Fig. 13

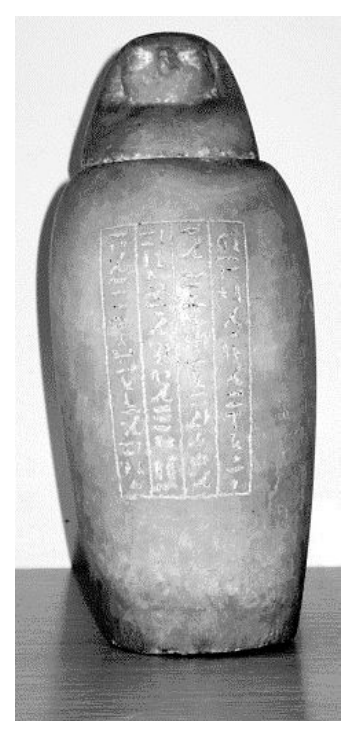

Fig. 14
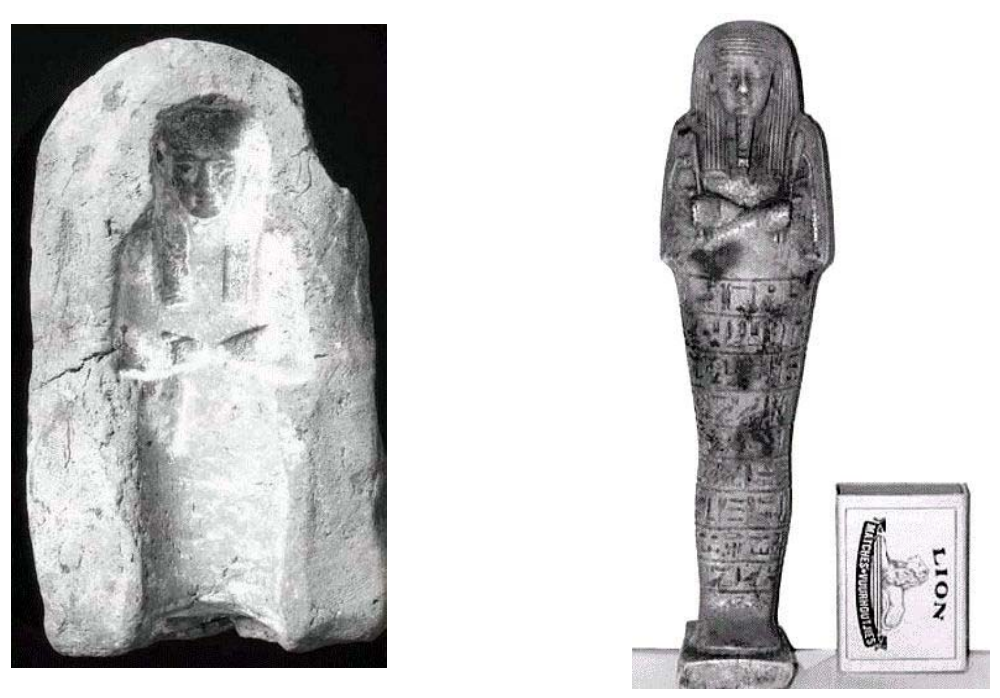

Fig. 15 
Fig. 17

Fig. 16
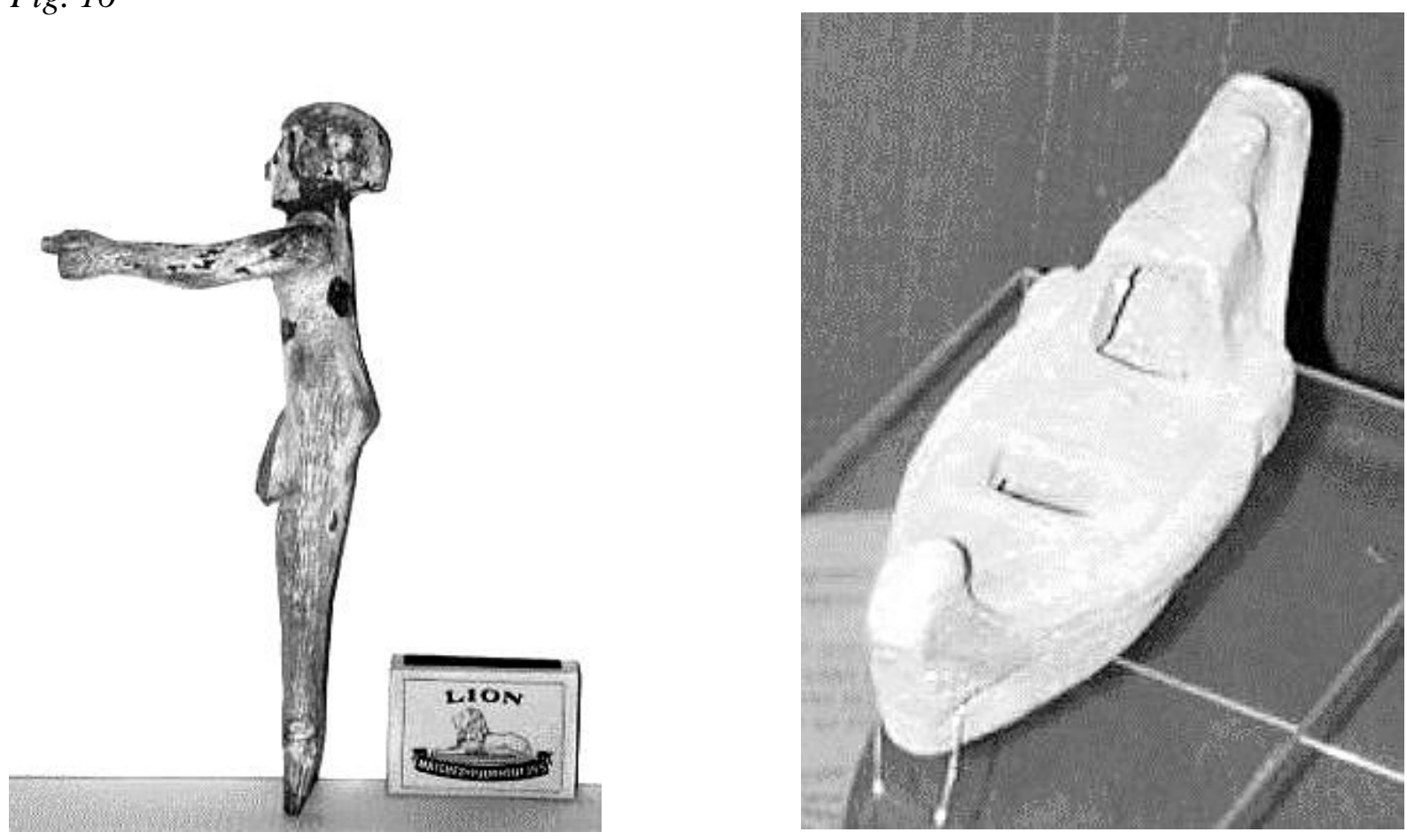

Fig. 18
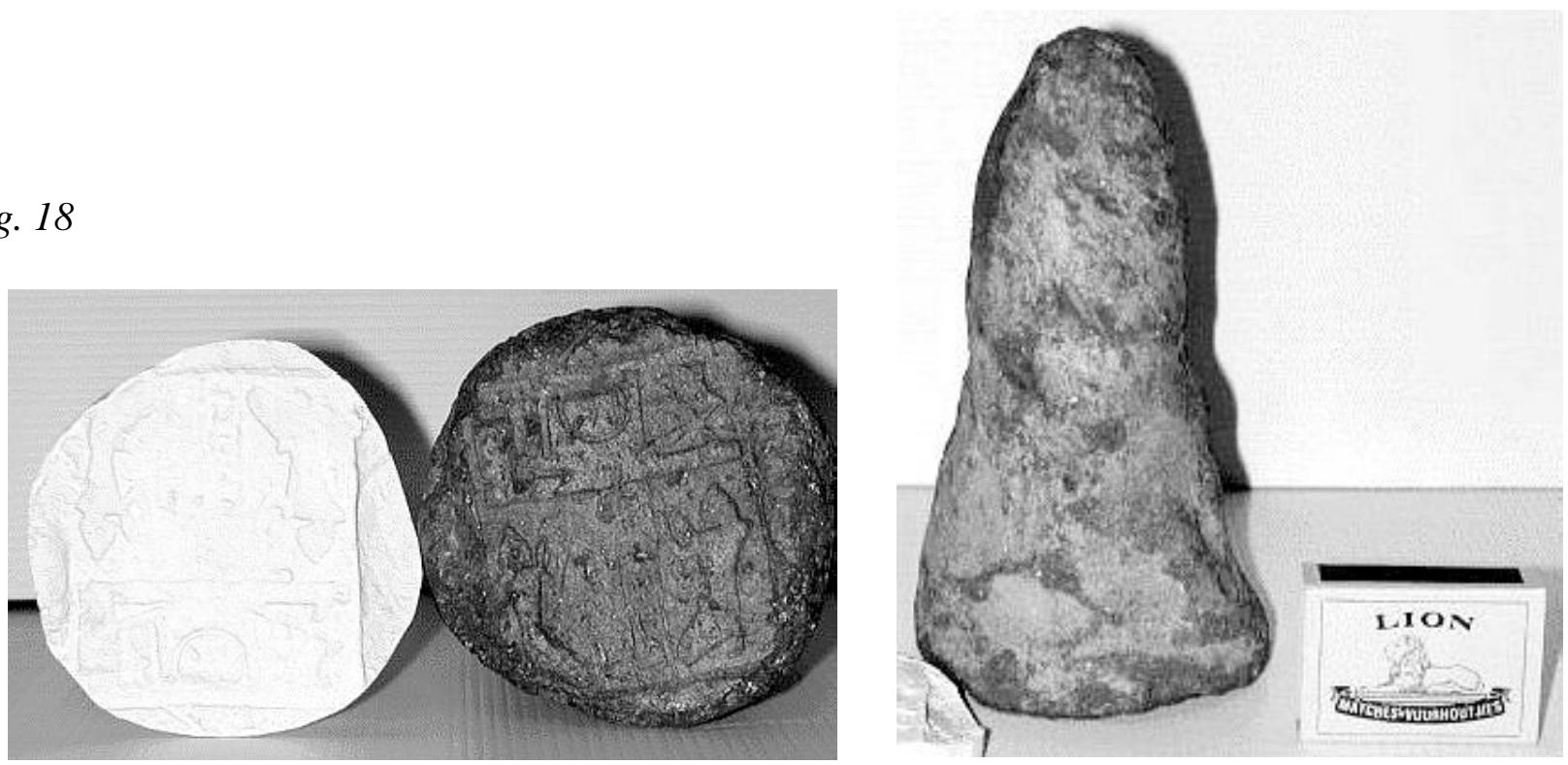